\title{
Algılanan Örgütsel Toksisitenin İş Doyumu Üzerine Etkisi: Duygusal Bağlılığın Aracılık Rolü
}

\author{
DOI: 10.26466/opus.537424
}

\author{
Gamze Kasalak $^{*}$ \\ *Öğr.Gör. Dr, Akdeniz Üniversitesi, Eğitim Fakültesi, Konyaaltı / Antalya / Türkiye \\ E-Posta: gamzekasalak@gmail.com \\ ORCID: $\underline{0000-0002-5084-0054}$
}

\section{Öz}

Bu araştırmanın amacı, araştırma görevlilerinin örgütsel toksisite algıları ile iş doyumları arasındaki ilişkide duygusal bağhllı̆̆ın aracı etkisini belirlemektir. Korelasyonel tarama modelinde benimsenmiş olan araştırmanın çalışma grubunda, basit tesadüfi örnekleme yöntemi ile seçilen ve Akdeniz Bölgesi'nde yer alan dört devlet üniversitesinde çeşitli akademik birimlerde görev yapan 253 araştırma görevlisi yer almaktadır Araştırmada veriler, demografik bilgileri içeren maddeler ile algılanan örgütsel toksisite ölçeği, duygusal bağhllık ölçeği ve iş doyumu ölçeği'nin yer aldı̆̆g bir form aracılığıyla toplanmıştır. Araştırma görevlilerinin örgütsel toksisite algıları, iş doyumları ve kurumlarına ilişkin duygusal bağlllıkları arasındaki ilişkiler Pearson korelasyon katsayıları ile incelenmiştir. Araştırma görevlilerinin duygusal bağlllık ve iş doyumları düzeylerinin algilanan örgütsel toksisite tarafindan yordanma durumlarını belirlemek için yapısal eşitlik modeli oluşturulmuştur. Bulgular, algılanan örgütsel toksisite ile iş doyumu ve duygusal bağhllık arasinda negatif yönlü, orta düzeyde ve anlamlı korelâsyonlar olduğunu göstermiştir. Bununla birlikte algılanan örgütsel toksisite iş doyumu ve duygusal bağgllık değişkenlerini anlamlı bir şekilde yordamaktadır. Ayrıca, algılanan örgütsel toksisite ile iş doyumu arasındaki ilişkide duygusal bă̆lılı̆̆ın kısmi aracılık rolü bulunmaktadır.

Anahtar Kelimeler: Algılanan örgütsel toksisite, Toksik davranışlar, Iş doyumu, Duygusal bağlllık 


\title{
The Effect of Perceived Organizational Toxicity on Job Satisfaction: The Mediating Role of Affective Commitment
}

\begin{abstract}
The purpose of this study is to determine whether affective commitment has a mediator role in the relationship between organizational toxicity perceptions of the research assistants and job satisfaction. This study is a correlational survey model. The sample of the study consists of 253 research assistants, working at four state universities located in the Mediterranean Region in Turkey, who were selected by stratified sampling method. The data were collected through a questionnaire comprising four sections: demographic questions, the perceived organizational toxicity scale, job satisfaction scale and affective commitment scale. The relations between the perceived organizational toxicity, the job satisfaction and af fective commitment were examined through Pearson correlation coefficient. That whether perceived organizational toxicity was a significant predictor of job satisfaction and affective commitment were examined using structural equation modeling. Findings show that there is a negative, moderate level and significant correlation among perceived organizational toxicity and job satisfaction, perceived organizational toxicity and the affective commitment. The perceived organizational toxicity is a significant predictor of job satisfaction and the affective commitment. Path analysis results indicated that affective commitment has a partial mediating role between that perceived organizational toxicity and job satisfaction.
\end{abstract}

Keywords: Perceived organizational toxicity, Toxic behaviors, Job satisfaction, Affective commitment 


\section{Giriş}

Fen ve sağlık bilimlerine dayalı bir kavram olan toksik kavramı LipmanBlumen (2005, s.17) tarafından "zehirli etkiye sahip olan" anlaminda kullanılmıştır. Toksisite kavramı ise "zehirli olma durumu" (Online Etymology Dictionary, 2014) şeklinde ifade edilmiştir. Toksik ve toksisite kavramları, Whicker (1996) tarafından ilk kez sosyal bilimler alanında ifade edilmiştir. Örgüt ve yönetim alanyazına toksisite kavramını yeni bir kavram olarak kazandırarak "örgütsel toksisite" yi tanımlayan ilk yazar ise Frost (2003)'tur. Kuramsal temelleri ihtiyaçlar hiyerarşisi, kendini sınıflandırma, lider-üye etkileşimi, psikodinamik, sosyal kimlik ve sosyal öğrenme kuramlarına (Lipman-Blumen, 2005; Lubit, 2003; O'Leary-Kelly, Griffin ve Glew, 1996; Pelletier, 2009) dayanan örgütsel toksisite, “işgörenlerin iş ortamlarında acı çekmeleri ve sorunlar yaşamalarına neden olan, moral ve güdülemelerini olumsuz yönde etkileyerek işlerine olan ilgiyi azaltan durumlar" ve "kurumlarda işgörenlerin özgüvenlerini ve saygınlıklarını yıkıcı acılar" (Frost, 2003, s.13-14) olarak tanımlanmıştır. Bir başka ifadeyle, "bireyleri işlerinden, iş arkadaşlarından ve çalıştıkları kurumlardan ayıran ve onların enerjilerini tüketen yaygın, yoğun ve olumsuz duygular"dır (Maitlis, 2008, s.1203). Frost'a (2003, s.5) göre çalışma ortamlarında yaşanan duygusal acılar, toksisite olarak görülmektedir. Örgütsel toksisite kavramının tanımında acı kavramına değinildiğinden bahsedilebilir. Hançerlioğlu'na göre (2000, s.18) acı kavramı, “hoşa gitmeyen duygulanım"dır. TDK'da (2015)ise acı "herhangi bir dış etken dolayısıyla duyulan rahatsızlık, ızdırap" ve mecazi olarak "kırıcı, üzücü, incitici, dokunaklı, kötü" olarak tanımlanmaktadır. Dolayısıyla tüm tanımlardan yola çıkarak örgütsel toksisite, işgörenlerde sıkıntı oluşturan, onlara zararı dokunan, yararı olmayan ve acı veren durumlar olarak tanımlanabilir. Sonuçta, kurumların örselenmesi ya da yaralanmasına neden olabilecek durumlar oluşabilir.

Kurumların zehirlenmesinde toksik işgören/liderlerin davranışlarını ile kişilik özelliklerini kapsayan bireysel kaynaklı faktörlerin etkili olduğundan söz edilmektedir (Appelbaum ve Roy-Girard, 2007; Carlock, 2013; Friedman 2005; Leet, 2011; Musacco, 2009; Pelletier, 2009; Schmidt, 2008). Alanyazında kurumların narsist, saldırgan, etik dışı ve katı davranışları kapsayan toksinler sonucunda zehirli duruma geldiğinden söz 
edilmektedir (Carlock, 2013; Gangel, 2007; Leet, 2011; Pelletier, 2009; Lubit, 2003; Riley, Hatfield, Nicely, Keller-Glaze ve Steele, 2011; Schmidt, 2008). Narsist davranışlar kaynaklı toksinler başkalarını küçük ve değersiz görme; aşağılayıcı davranışlar sergileme, kendini beğenme ve övme, başkalarının yaptıklarını hor görme ile ilişkilidir (Goldman, 2009; Lubit, 2003; Twenge ve Campbell, 2010). Saldırgan davranışlar kaynaklı toksinler ile bireylerin başkalarını kıskanma ve taraf olmaya zorlama,onlara iftirada bulunma ve asılsız dedikodularda bulunma durumları betimlenirken; etik dışı davranışlar kaynaklı toksinler ile de işgörenlerden görevleri dışında işler bekleme, işgörenlerin iş yüklerini haksız biçimde artırma ve özlük haklarının kullanımına engel olma durumları ortaya çıkabilmektedir (Frost, 2003; Lubit, 2003). Son toksin ise nezaketten uzak davranışlar sergileme, başkalarına saygı göstermeme, sinsice saygısızlık yapma ve k1rıcı sözler sözleme durumları ile betimlenen katı davranışlar kaynaklı toksinlerden (Frost, 2003) oluşmaktadır. Tüm bu toksinler bir kişiyi ya da bütün bir kuruluşu zehirleyebilecek durumda olduğu için işgörenlerin iş doyumlarını ve kurumlarına ilişkin duygusal bağlılıklarını olumsuz yönde etkilemesi beklenebilir.

Alanyazında algılanan örgütsel toksisitenin çeşitli değişkenlerle olan ilişkisi, ilgili araştırma sonuçlarıyla desteklenmektedir. Örneğin, Holloway ve Kusy (2010) iş yaşamında toksisite algılayan işgörenlerde işten ayrılma niyetlerinde artış; işyerinde zaman geçirmede ve kuruma olan bağlılıklarında düşüş; işgörenlerin iş kaliteleri, gayretleri ve performanslarında düşüş; endişe düzeylerinde artış saptamışlardır. Pelletier (2012) liderin oluşturduğu zehirlenmenin işgörende eşitsizlik, bölücülük, istismarcılık ve sosyal dışlanmışlık algısına neden olduğu bulgusuna ulaşmıştır. Örgütsel toksisite, işgörenlerin örgütsel şeffaflık düzeylerini azaltmakta; yaratıcılıklarına, morallerine ve üretkenliklerine zarar vermektedir (Porter-O'Grady ve Malloch, 2010; Walton, 2007). Ayrıca, örgütsel sadakatlerini zedelemekte, örgütsel güven ve yöneticiye memnuniyeti azaltmakta, örgütsel sabotajı artırmakta, örgüt içi iletişim ile örgütsel sosyal sermayeyi bozmaktadır (Frost, 2003; Holloway ve Kusy, 2010; Lubit, 2003). Tüm bu çalışmalara dayalı olarak algılanan örgütsel toksisitenin iş doyumu ile duygusal bağlılık değişkenleri için önemli birer yordayıcı değişkenler olduğu varsayılmaktadır. 
İş doyumu, Locke'a (1976) göre işgörenlerin işlerinde kendilerine verilmiş rol ve görevlere değer biçilmesi sonucunda elde edilen duyuşsal kaynaklı tepki (Dotan, 2007) olarak tanımlanmaktadır. Peterson ve Deal'a (2009) göre, toksisitenin bulunduğu okullarda çalışmak eğlenceli değildir, keyif vermez ve doyum sağlamaz. Sonuçta bireylin güdülenme ve bağlllık düzeyi de zayıftır. İş doyumu ile iş yaşamında toksisite arasındaki ilişkinin varlığı birçok araştırmada ele alınmış ve kanıtlanmıştır (Mackie, 2008; Mehta ve Maheshwari, 2013; Schmidt, 2008; Webster, Brough ve Daly, 2016). Örneğin; narsizm kaynaklı toksin iş doyumunun anlamlı yordayıcılarından biri olup; aralarında olumsuz yönde bir ilişkinin varlığından söz edilmektedir (Jonason, Wee ve Li, 2015; O’Boyle, Forsyth, Banks ve McDaniels, 2012). Etik dışı ve saldırgan kaynaklı toksinler ile iş doyumu arasındaki ilişkiyi ele alan bir çalışmada orta düzeyde negatif ilişkiler ortaya çıkmış; bununla birlikte örgütlerin karanlık yönü olan tüm özelliklerin iş doyumunu yüzde 45 ile yüzde 51 oranları arasında yordadığı ortaya konulmuştur (Mathieu, Neumann, Hare ve Babiak, 2014). Ayrıca bir çalışmada iş yaşamında toksisite ile iş doyumu ilişkisi liderlik davranışı bağlamında incelenmiştir. Toksik liderliğin lider, iş, ücret ve meslektaş kaynaklı doyumu doğrudan ve olumsuz yönde etkilediği sonucu elde edilmiştir (Schmidt, 2008). Sonuçta, çalıştığ kurum ya da ortamda toksinlere maruz kalarak zehirlendiği algısına sahip bireylerin kendilerine verilmiş rol ve görevleri severek yapmaları, mutluluğu iş yerinde bulmak istemeleri, yaptıkları işten memnun olmaları ve işyerinde zaman geçirmekten memnun olmaları zor olabilir.

Algilanan örgütsel toksisitenin etkilediği bir diğer faktör de duygusal bağl1lıktır. Meyer ve Allen (1991, s.64) duygusal bağlılığı, bireyin çalıştığ1 kurumla özdeşleşmesi ve duygusal açıdan çalıştığı kuruma bağlanması olarak tanımlamaktadır. Bireylerin kurumlarına ilişkin duygusal bağlılıkları, kurumlarda bireysel ve örgütsel değerlerin belirli bir uyum içerisinde bulunmasıyla oluşmaktadır. Sonuçta birey, çalıştığı kurumun üyesi olmaktan mutluluk duyacaktır (Wiener, 1982, s.423). Lider/işgören kaynaklı toksisitenin örgütsel bağlllık üzerinde olumsuz etkilerinin olduğunu ele alan çeşitli sayıda çalışmalara rastlamak mümkündür (Holloway ve Kusy, 2010; Mehta ve Maheshwari, 2013). Holloway ve Kusy (2010), toksik davranışlara maruz kalan bireylerin yüzde 12'sinin işinden ayrılma, yüzde 48 'inin iş gayretlerinde azalma, yüzde 47 'sinde işyerinde zaman geçirme 
durumlarında azalma, yüzde $38^{\prime}$ inde iş kalitesinde azalma, yüzde $68^{\prime}$ inde iş performansinda düşüş, yüzde 80 'inde endişe yaşama, yüzde 63'ünde toksik davranışları sergileyen kişiden kaçarak vakit kaybetme ve yüzde 78'inde kurumlarına olan bağlılıklarında azalma gözlemlemişlerdir. Mehta ve Maheshwari (2013), lider kaynaklı toksisitenin liderin takipçilerinin psikolojilerini ve örgütsel bağlılık durumlarını olumsuz yönde etkilediklerini belirtmişlerdir. Ayrıca, bir başka araştırmacı yetenekli bireyleri potansiyel tehditler olarak gören liderlerin, yetenekli işgörenlerin güçlerini sınırlandırdıkları ve önemli takım üyeleri arasındaki ilişkileri bozarak astları kontrol altında tuttuklarını; böylece liderlerin bu tarz davranışlarla kurum içerisinde toksik etkiler oluşturduklarını belirtmiştir (Pelletier, 2009). Toksik etkilerin yoğun olduğu kurumlarda da güdülenme ve örgütsel bağlılık zayıftır (Peterson ve Deal, 2009). Tüm bu araştırma bulguları ve görüşler sonucunda, çalıştığı kurum ya da ortamda acı veren durumlara maruz kalarak zehirlendiği algısına sahip işgörenlerin kariyerlerinin geri kalan kısmını aynı işyerinde geçirmekten mutlu olmaları, kendilerini ailenin bir parçası gibi hissetmeleri ve kurumları onlar için özel bir anlam ifade etmeleri zor olabilir.

Tüm görüşlere dayalı olarak, bireylerin kurumlarını zehirli olduğunu algılamalarının iş doyum ve kurumlarına ilişkin duygusal bağlılık düzeylerini düşürdüğünden bahsedilebilir. Başka bir değişle, algılanan örgütsel toksisitenin bireylerin iş doyumu ve duygusal bağlllık düzeylerini olumsuz yönde etkilemesi beklenmektedir. Bununla birlikte, duygusal bağl111ğın algılanan örgütsel toksisite ile iş doyumu arasındaki ilişkiler üzerideki dolaylı rolünün ne kadar olduğu miktarı bilinememektedir. Dolayısıyla duygusal bağl1lığının düşük olduğu bir dönemde, algılanan örgütsel toksisitenin duygusal bağlılık üzerindeki ve duygusal bağlılı̆̆ın iş doyumu üzerindeki doğrudan rolünün belirlenmesine ihtiyaç vardır. Tüm bu açılamalar doğrultusunda bu araştırmada algılanan örgütsel toksisitenin iş doyumu üzerindeki doğrudan ve duygusal bağlılık aracilığı ile dolaylı etkisi belirlenmeye çalışılmıştır. Bu araştırmada, araştırma görevlilerinin örgütsel toksisite algıları, iş doyumları ile kurumlarına ilişkin duygusal bağlılıkları arasındaki ilişkiler incelenmiştir. Araştırmanın temel amacı doğrultusunda, Şekil 1'deki teorik model test edilmiş ve aşağıda yer alan sorulara yanıt aranmıştır: 
1. Araştırma görevlilerinin örgütsel toksisite algıları, iş doyumları ve kurumlarına ilişkin duygusal bağlılıkları arasında anlamlı bir ilişki var mıdır?

2. Araştırma görevlilerinin kurumlarına ilişkin duygusal bağl1lıkları ve iş doyumları örgütsel toksisite algıları tarafından anlamlı bir şekilde yordanmakta mıdır?

a. Araştırma görevlilerinin örgütsel toksisite algıları kurumlarına ilişkin duygusal bağlılıklarını anlamlı bir şekilde yordamakta midır?

b. Araştırma görevlilerinin örgütsel toksisite algıları iş doyumlarını anlamlı bir şekilde yordamakta mıdır?

c. Araştırma görevlilerinin örgütsel toksisite algıları ile iş doyumları arasındaki ilişkide kurumlarına ilişkin duygusal bağlılığın aracı etkisi var mıdır?

Duygusal bağlılık (DB) aracı değişkeni, araştırmanın 2. Yapısal eşitlik modelinde yer almaktadır.

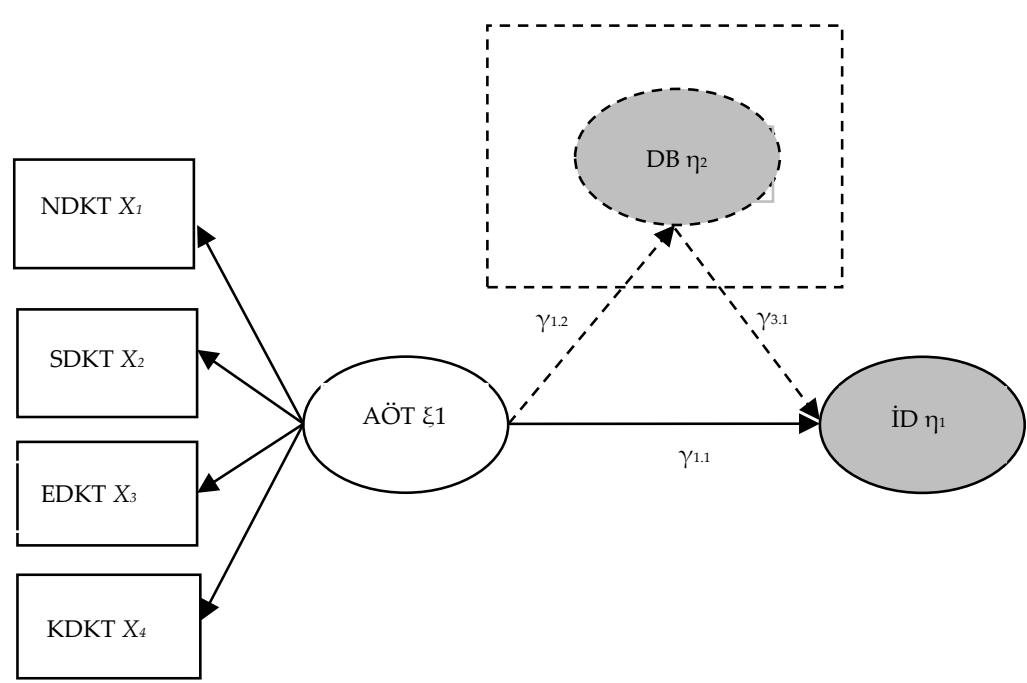

AOT: Algılanan örgütsel toksisite, NDKT: Narsist davranışlardan kaynaklanan toksisite, SDKT: Saldırgan davranışlardan kaynaklanan toksisite, EDKT: Etik dışı davranışlardan kaynaklanan toksisite, KDKT: Katı davranışlardan kaynaklanan toksisite, DB: Duygusal bağlılık, ID: İş doyumu

Şekil 1. Araştırma kapsamında oluşturulan teorik yapısal model 
Şekil 1, araştırma görevlilerinin algılarına göre duygusal bağlılık ve iş doyum düzeylerinin algılanan örgütsel toksisite tarafından anlamlı bir şekilde yordanıp yordanmadığı geliştirilen iki yapısal eşitlik modeli ile bağımlı ve bağımsız ölçüm modelleri tarafından incelenmesini ortaya koymaktadır. Teorik modellerden ilki i) algılanan örgütsel toksisitenin iş doyumu üzerindeki etkisini; ii) ikincisi de algılanan örgütsel toksisite ile iş doyumu arasındaki ilişkide duygusal bağlılığın aracı etkisini incelemektedir. İkinci teorik modelin bağımsız ölçüm modelinde, algılanan örgütsel toksisite hem gizil dışsal hem de bağımsız değişkendir. Algılanan örgütsel toksisiteyi oluşturan boyutlar (narsist, saldırgan, etik dışı ve katı davranışlardan kaynaklanan toksisite) ise bağımsız gözlenen değişkenlerdir. Bağımlı ölçüm modelinde, iş doyumu değişkeni hem gizil içsel hem de bağımlı değişkendir. Bağımlı gözlenen değişkenler de, iş doyumunu oluşturan ifadelerdir. Ayrıca, Holmbeck'in (1997) görüşüne dayalı olarak duygusal bağlılık aracı değişken olarak tanımlanmıştır. Aracı değişken olan duygusal bağlılığın analize dâhil edilmesiyle birlikte bağımlı (iş doyumu) ve bağımsız değişken (algılanan örgütsel toksisite) arasındaki ilişkinin istatistiksel olarak anlamlı bir şekilde azalması öngörülmüştür. Dolayısıyla bu modelde, araştırma görevlileri tarafından algılanan örgütsel toksisite dışsal bağımsız değişkeni ile iş tatmini içsel bağımlı değişkeni arasındaki ilişkide duygusal bağlılık aracı değişkenin aracı etkisinin olduğu varsayılmiştır.

\section{Yöntem}

\section{Araştırmanın Modeli}

Araştırma görevlilerinin örgütsel toksisite algıları, iş doyumları ile kurumlarına ilişkin duygusal bağlılıkları arasındaki ilişkilerin ortaya konduğu bu araştırma, iş doyumu bağımlı değişkeni ile duygusal bağlılık aracı değişkeninin algılanan örgütsel toksisite bağımsız değişkeni tarafından yordanmasinı incelemek amaciyla korelasyonel tarama modelinde tasarlanmiştır. 


\section{Çalışma Grubu}

Araştırmanın çalışma grubunda, olasılık temelli örnekleme yöntemlerinden basit tesadüfî örnekleme yöntemi esas alınarak belirlenen ve Akdeniz Bölgesi'nde yer alan dört devlet üniversitesindeki farklı akademik birimlerde görev yapan 253 araştırma görevlisi bulunmaktadır. Araştırma görevlilerinin 127'si kadın ve 126'sı da erkektir. Araştırma görevlilerinin 122 'si (\% 49.6) sosyal ve beşeri bilimler, 74'ü (\% 30.1) fen bilimleri ve 50'si (\% 20.3) sağlık bilimleri alanında görev yapmaktadır. Araştırma görevlilerinin yaş aralıkları 23 ile 36 arasında değişmekte olup; yaş ortalamaları 28.74 olarak hesaplanmıştır. Görev yaptıkları üniversitedeki ortalama hizmet süreleri ise 3.67 yıl olup, 1 ile 14 yıl arasında değişmektedir.

\section{Veri Toplama Araçları}

Araştırmanın verileri demografik bilgileri içeren maddeler ile Algılanan Örgütsel Toksisite Ölçeği, İş Doyumu Ölçeği ve Duygusal Bağlılık Ölçeği'nin yer aldığı bir form aracılığıyla toplanmıştır.

Algılanan Örgütsel Toksisite Ölçeği (AÖTÖ). Araştırma görevlilerinin örgütsel toksisite algılarını belirlemek amacıyla Kasalak (2015) tarafından geliştirilen Algılanan Örgütsel Toksisite Ölçeği (АÖTÖ) kullanılmıştır. Beş noktalı Likert tipi [Hiçbir zaman (1), Nadiren (2), Ara sıra (3), Sık sık (4) ve Her zaman (5)] derecelendirme kullanılan Algılanan Örgütsel Toksisite Ölçeği (AÖTÖ), 16 madde ve dört boyuttan oluşmaktadır. Bu dört boyut; i) Narsist Davranışlardan Kaynaklanan Toksisite (NDKT) (Örnek madde: Çalıştı̆̆ım kurumda/ortamda küçümseyici tavırlar sergilenir.), ii) Saldırgan Davranışlardan Kaynaklanan Toksisite (SDKT) (Örnek madde: Çalıştığım kurumda/ortamda asılsız dedikodular çıkarılır.), iii) Etik Dışı Davranışlardan Kaynaklanan Toksisite (EDKT) (Örnek madde: Çalıştığım kurumda/ortamda kural ve mevzuata aykırı davranılır.) ve iv) Katı Davranışlardan Kaynaklanan Toksisite (KDKT) (Örnek madde: Çalıştığım kurumda/ortamda nezaketten uzak tavırlar sergilenir.) olarak adlandırılmı̧̧tır. NDKT boyutu dört (faktör yükleri: 0.723-0.785), SDKT boyutu dört (faktör yükleri: 0.662-0.836), EDKT boyutu dört (faktör yükleri: 0.6270.816) ve KDKT boyutu da dört (faktör yükleri: 0.645-0.829) maddeden 
oluşmaktadır. Açıklanan varyans oranları ilk boyut için yüzde 47,836 (özdeğer=7.654), ikinci boyut için yüzde 8.566 (özdeğer=1.371), üçüncü boyut için yüzde 7,444 (özdeğer=1.191) ve dördüncü boyut için yüzde 6,604 (özdeğer=1.057) olmak üzere toplam yüzde 70,451 olarak belirlenmiştir (Kasalak, 2015). Bu çalışma için gerçekleştirilen açıklayıcı faktör analizi sonucunda, ölçeğin açklanan varyans oranları NDKT için yüzde 17.86 (faktör yükleri: 735-.747), SDKT için yüzde 17.31 (faktör yükleri: .537-880), EDKT için yüzde 17.45 (faktör yükleri: .603-.777) ve KDKT için yüzde 15.52 (faktör yükleri:.538-.835) olarak hesaplanmıştır. Kasalak (2015) ölçeğin doğrulayıcı faktör analizi sonucunda elde edilen modelin uyum indekslerini $[\chi 2=346.43, \mathrm{sd}=97, \mathrm{P}<0.001], \mathrm{RMSEA}=0.06, \mathrm{GFI}=0.94, \mathrm{AGFI}=0.92, \mathrm{NFI}=$ 0.95 ve $C F I=0.96$ olarak bulmuştur. Ayrıca, Cronbach alfa iç tutarlılık katsayılarını da NDKT için $\alpha=0.880$; SDKT için $\alpha=0.845$, EDKT için $\alpha=0.834$, KDKT için $\alpha=0.854$ ve ölçeğin bütünü için $\alpha=0.938$ olarak tespit etmiştir. $\mathrm{Bu}$ çalışmada ise, ölçeğin iç tutarlılık katsayısı tüm maddeler için 0.916 iken; boyutlara göre iç tutarlılık katsayıları sırasıyla $0.823 ; 0.851 ; 0.819$ ve 0.820 olarak hesaplanmıştır.

İş Doyumu Ölçeği (İDÖ). Brayfield ve Rothe (1951) tarafından geliştirilmiş ve Bilgin (1995) tarafından Türkçe'ye uyarlaması gerçekleştirilmiş iş doyumu ölçeği (IDÖ) ile, araştırma görevlilerinin iş doyum düzeylerinin belirlenmesi amaçlanmıştır. Beş noktalı Likert tipi [Hiç katılmıyorum (1), Katılmiyorum (2), Kismen katıliyorum (3), Katıliyorum (4) ve Tamamen katılıyorum (5)] derecelendirme kullanılan ölçek tek boyutlu bir yapıya sahip olup; ikisi ters maddeden toplamda beş maddeden oluşmaktadır (Örnek maddeler: İşyerinde zaman geçmek bilmiyor. Mutluluğu işimdeyken buluyorum.). Bu çalışma için gerçekleştirilen açıklayıcı faktör analizi sonucunda, ölçeğin açıklanan varyans oranı yüzde 51,89 olarak hesaplanmıştır. Ayrıca, gerçekleştirilen doğrulayıcı faktör analizi sonucunda da, elde edilen modelin uyum indeksleri [ $\chi 2=9.19$, sd $=4, \mathrm{P}<0.001]$, RMSEA $=$ $0.072, \mathrm{GFI}=0.99$, $\mathrm{AGFI}=0.96, \mathrm{NFI}=0.98$ ve $\mathrm{CFI}=0.99$ olarak bulmuştur. Alanyazında bu ölçeği kullanan araştırmacılar ölçeğin iç tutarlık katsayısinı 0.750 (Alan, 2011; Ömüriş, 2014) belirlerken; bu çalışmada ölçeğin iç tutarlık katsayısı 0.764 şeklinde belirlenmiştir. 
Duygusal Bağlılık Ölçeği (DBÖ). Allen ve Meyer (1990) tarafından geliştirilmiş ve Wasti (2000) tarafından Türkçe'ye uyarlaması gerçekleştirilmiş bu ölçek ile araştırma görevlilerinin duygusal bağlllık düzeylerinin belirlenmesi amaçlanmıştır. Beş noktalı Likert tipi [Hiç katılmıyorum (1), Katılmiyorum (2), Kismen katılıyorum (3), Katıliyorum (4) ve Tamamen katılıyorum (5)] derecelendirme kullanılan ölçek, örgütsel bağlılık ölçeğinin bir alt boyutu olup altı maddeden oluşmaktadır (Örnek madde: İşyerimde kendimi ailenin bir parçası olarak hissederim.). Bu çalışma için gerçekleştirilen açıklayıcı faktör analizi sonucunda, ölçeğin açıklanan varyans oranı yüzde 66,40 olarak hesaplanmıştır. Ayrıca, gerçekleştirilen doğrulayıc faktör analizi ile, uyum indeksleri $[\chi 2=49.37$, sd $=9, \mathrm{P}<0.001]$, RMSEA $=0.13, \mathrm{GFI}=0.94, \mathrm{AGFI}=0.86, \mathrm{NFI}=0.96$ ve $\mathrm{CFI}=0.97$ olarak elde edilmiştir. Wasti (2000) duygusal bağlılık ölçeğinin iç tutarlık katsayısını 0.83 olarak hesaplarken; bu çalışmada ölçeğin iç tutarlık katsayısı 0.898 şeklinde belirlenmiştir.

\section{Verilerin Toplanması ve Analizi}

Veriler, Akdeniz Bölgesi'nde yer alan dört devlet üniversitesinde farklı akademik birimlerde görev yapan araştırma görevlilerinden araştırmac1nın kontrolünün artacağı, zaman ve maliyet açısından önemli tasarruflar sağlanacağı (Büyüköztürk, 2005) düşüncesiyle araştırmacının kendisi tarafından toplanmış; tüm analizler için SPSS 13.0 ve LISREL 9.2 paket programlarından yararlanılmıştır. Araştırma görevlilerinin örgütsel toksisite algıları, duygusal bağlılık ile iş doyumu düzeyleri arasındaki ilişkiler Pearson korelasyon katsayıları ile incelenmiştir. Araştırma görevlilerinin örgütsel toksisite algılarının iş doyumu üzerindeki etkisi ile araştırma görevlilerinin örgütsel toksisite algıları ile iş doyumları arasındaki ilişkide duygusal bağlılı̆̆ın aracı etkisinin incelenmesi Path analizi kullanılarak gerçekleştirilmiştir. Araştırma kapsamında oluşturulan teorik yapısal eşitlik modellerinin test edilmesinde elde edilen uyum iyiliği indeksleri olan RMSEA ve SRMS değerlerinin 0.10'dan küçük; GFI, AGFI, NFI, CFI değerlerinin ise 0.90 'dan büyük olmasina (Schermelleh-Engel, Moosbrugger ve Müller, 2003) dikkat edilmiştir. Ayrıca ki-kare ( $\chi 2)$ uyum testinin serbestlik derecesine ( $\chi 2 / \mathrm{sd}$ ), oranının 1-5 arası değerlerde olması (Sümer, 2000) ölçüt olarak kullanılmıştır. Ayrıca araştırma görevlilerinin örgütsel 
toksisite algıları ile iş doyumları arasındaki ilişkide kurumlarına ilişkin duygusal bağlılığın aracı etkisinin anlamlı olup olmadığı Sobel testi hesaplaması ile gerçekleştirilmiştir.

\section{Bulgular}

\section{Değişkenler Arasındaki İlişkilere Yönelik Bulgular}

Araştırma görevlilerinin örgütsel toksisite algıları, iş doyumları ile kurumlarına ilişkin duygusal bağlılık değişkenlerine ilişkin aritmetik ortalama, standart sapma ve Pearson korelâsyon katsayı değerleri Tablo 1'de bulunmaktadir.

Tablo 1. Araştırma görevlilerinin örgütsel toksisite algıları, iş doyumları ve kurumlarına ilişkin duygusal bağlilikları arasındaki ilişkiler

\begin{tabular}{lclllllll}
\hline & $\overline{\mathrm{X}}$ & SS & $\mathbf{1}$ & $\mathbf{2}$ & $\mathbf{3}$ & $\mathbf{4}$ & $\mathbf{5}$ & $\mathbf{6}$ \\
\hline 1.NDKT-AÖT & 2.53 & .73 & 1 & & & & & \\
2. SDKT-AÖT & 2.42 & .87 & $.618^{*}$ & 1 & & & & \\
3.EDKT-AÖT & 2.60 & .96 & $.562^{*}$ & $.591^{*}$ & 1 & & & \\
4.KDKT-AÖT & 2.77 & .98 & $.541^{*}$ & $.575^{*}$ & $.554^{*}$ & 1 & & \\
5.Genel-AÖT & 2.58 & .73 & $.801^{*}$ & $.840^{*}$ & $.831^{*}$ & $.824^{*}$ & 1 & \\
6.DB & 3.18 & .90 & $-.321^{*}$ & $-.299^{*}$ & $-.245^{*}$ & $-.255^{*}$ & $-.335^{*}$ & 1 \\
7.ID & 3.64 & .75 & $-.369^{*}$ & $-.277^{*}$ & $-.281^{*}$ & $-.250^{*}$ & $-.351^{*}$ & $.589^{*}$ \\
\hline
\end{tabular}

${ }^{*} p<.01$

Araştırma görevlilerinin algılanan örgütsel toksisite ortalamaları incelendiğinde; en yüksek aritmetik ortalama katı davranışlardan kaynaklanan toksisite $[\overline{\mathrm{X}}=2.77, \mathrm{SS}=0.98]$; en düşük aritmetik ortalama ise saldırgan davranışlardan kaynaklanan toksisite $[\overline{\mathrm{X}}=2.42$, SS=0.87] boyutuna aittir. Araştırma görevlilerinin örgütsel toksisite algıları, iş doyumları ile kurumlarına ilişkin duygusal bağlllıklarına ilişkin aritmetik ortalamalar incelendiğinde, en yüksek ortalama iş doyumu $[\overline{\mathrm{X}}=3.64, \mathrm{SS}=0.75]$ ve en düşük ortalama ise algılanan örgütsel toksisite $[\bar{X}=2.58, S S=0.73]$ için hesaplanmıştır.

Algılanan örgütsel toksisite ve boyutları ile iş doyumu arasında negatif yönde ve anlamlı ilişkiler bulunmaktadır. Narsist davranışlardan kaynaklanan toksisite $(r=-0.369, p<0.01)$ ve genel algılanan örgütsel toksisite $(r=$ 
-0.351, $\mathrm{p}<0.01)$ iş doyumu ile negatif yönde ve orta düzeyde; saldırgan davranışlardan kaynaklanan toksisite $(r=-0.277, p<0.01)$, etik dışı davranışlardan kaynaklanan toksisite $(\mathrm{r}=-0.281, \mathrm{p}<0.01)$ ve katı davranışlardan kaynaklanan toksisite $(\mathrm{r}=-0.250, \mathrm{p}<0.01)$ ise iş doyumu ile negatif yönde ve düşük düzeyde anlamlı ilişkiler kurmaktadır. Ayrıca, algılanan örgütsel toksisite ve boyutları ile duygusal bağlllık arasında negatif yönde ve anlamlı ilişkiler bulunmaktadır. Narsist davranışlardan kaynaklanan toksisite $(\mathrm{r}=-0.321, \mathrm{p}<0.01)$ ve genel algilanan örgütsel toksisite $(\mathrm{r}=-0.335$, $\mathrm{p}<0.01)$ duygusal bağll1ık ile negatif yönde ve orta düzeyde; saldırgan davranışlardan kaynaklanan toksisite $(\mathrm{r}=-0.299, \mathrm{p}<0.01)$, etik dışı davranışlardan kaynaklanan toksisite $(\mathrm{r}=-0.245, \mathrm{p}<0.01)$ ve katı davranışlardan kaynaklanan toksisite $(\mathrm{r}=-0.255, \mathrm{p}<0.01)$ ise duygusal bağlılık ile negatif yönde ve düşük düzeyde anlamlı ilişkiler kurmaktadırAraştırmada ayrıca, duygusal bağlılık ile iş doyumu arasındaki ilişkiler de incelenmiştir. Duygusal bağlılık ile iş doyumu $(\mathrm{r}=0.589, \mathrm{p}<0.01)$ arasında pozitif yönde ve orta düzeyde anlamlı ilişkiler hesaplanmıştır (Tablo 1).

\section{Teorik Modellerin İncelenmesine Yönelik Bulgular}

Oluşturulan her iki modele ait Path analizi sonuçlarına göre elde edilen uyum indeksleri Tablo 2'de sunulmuştur.

Tablo 2. Modellere ait uyum indeksleri bulgularn

\begin{tabular}{lllllllllll}
\hline & $\chi \mathbf{2}$ & sd & $\chi \mathbf{2} / \mathbf{s d}$ & RMSEA & GFI & AGFI & NFI & CFI & IFI & SRMR \\
\hline $\begin{array}{l}\text { Model } \\
1\end{array}$ & 82.25 & 26 & 3.16 & .093 & .93 & .88 & .93 & .95 & .95 & .066 \\
$\begin{array}{l}\text { Model } \\
2\end{array}$ & 239.28 & 87 & 2.75 & .083 & .89 & .84 & .94 & .96 & .96 & .060 \\
\hline
\end{tabular}

Tablo 2 incelendiğinde; Model 1 için $[\chi 2=82.25 ; \mathrm{sd}=26, \mathrm{p}=0.00<0.01$; $\chi 2 / \mathrm{sd}=3.16 ; \mathrm{RMSEA}=0.093 ; \mathrm{GFI}=0.93 ; \mathrm{AGFI}=0.88 ; \mathrm{NFI}=0.93 ; \mathrm{CFI}=0.95$, $\mathrm{IFI}=0.95$ ve $S R M R=0.066]$ ve Model 2 için $[\chi 2=239.28 ; \mathrm{sd}=87, \mathrm{p}=0.00<0.01$; $\chi 2 / \mathrm{sd}=2.75 ; \mathrm{RMSEA}=0.083 ; \mathrm{GFI}=0.89 ; \mathrm{AGFI}=0.84 ; \mathrm{NFI}=0.94 ; \mathrm{CFI}=0.96$, $\mathrm{IFI}=0.96$ ve $\mathrm{SRMR}=0.060$ ] elde edilen uyum indekslerinin "iyi" ve "kabul edilebilir uyum" içerisinde olduğunu göstermektedir (Kline, 2005). 
Her iki modele ait ilişkilerin anlamlı olup olmadığını belirlemek amacıyla hesaplanan standartlaştırılmamış regresyon matris değerleri $(\beta)$ ve " $t$ " testinden elde edilen değerler Tablo 3 'de sunulmuştur.

Tablo 3. Modellere ilişkin standartlaştırılmamış regresyon matrisi ve " $t$ " değerleri

\begin{tabular}{|c|c|c|c|c|c|c|c|}
\hline \multirow{2}{*}{$\frac{7}{8}$} & \multirow{2}{*}{ 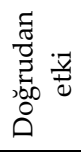 } & Bağımsız Değişken & \multicolumn{2}{|l|}{$\begin{array}{l}\text { Bağımlı } \\
\text { Değişken }\end{array}$} & $\beta(\lambda)$ & $t$ & $\mathbf{R}^{2}$ \\
\hline & & $\begin{array}{l}\text { Algılanan Örgütsel Toksi- } \\
\text { site }\end{array}$ & İş doyumu & & -0.42 & $-5.36^{* *}$ & 0.18 \\
\hline \multirow{2}{*}{ 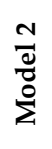 } & \multirow{2}{*}{$\begin{array}{l}\overrightarrow{\vec{y}} \\
\overrightarrow{0} \\
\overrightarrow{0} \\
\frac{\vec{\sigma}}{0} \\
0\end{array}$} & Bağımsız Değişken & $\begin{array}{l}\text { Bağımlı } \\
\text { Değişken }\end{array}$ & $\begin{array}{l}\text { Aracı } \\
\text { Değişken }\end{array}$ & $\beta(\lambda)$ & $t$ & $\mathbf{R}^{2}$ \\
\hline & & $\begin{array}{l}\text { Algılanan Örgütsel Toksi- } \\
\text { site }\end{array}$ & İş doyumu & $\begin{array}{l}\text { Duygusal } \\
\text { Bağlllık }\end{array}$ & -0.19 & $-2.90^{* *}$ & 0.53 \\
\hline
\end{tabular}

Model 1'e ilişkin standartlaştırılmış path katsayıları incelendiğinde algılanan örgütsel toksisitenin iş doyumuna doğrudan etkisinin negatif yönde ve anlamlı olduğu görülmektedir ( $\$=-.42$, $\mathrm{p}<0.01$ ) (Tablo 3). Alg1lanan örgütsel toksisite duygusal bağlllı̆̆ı da negatif yönde ve anlamlı bir şekilde etkilemektedir ( $(=-.36, \mathrm{p}<0.01)$. Duygusal bağllığın iş doyumu üzerindeki doğrudan etkisi incelendiğinde de pozitif yönde ve anlamlı bir etki gözlenmiştir ( $\beta=.63, \mathrm{p}<0.05$ ) (Şekil 2 ). Araştırmada araştırma görevlilerinin örgütsel toksisite algıları iş doyumları arasındaki ilişkide kuruma ilişkin duygusal bağlılık aracı değişken olarak belirlenmiştir. Duygusal bağlılı̆̆ın aracı değişken olarak etkisi incelendiğinde, algılanan örgütsel toksisite ile iş doyumu arasındaki ilişkiye dolaylı katkısı anlamlı $(\mathrm{z}=$ 7.61240363, p<0.001), negatif yönde ve düşük düzeyde olduğu tespit edilmiştir ( $(=-.19$ ). Başka bir ifadeyle, duygusal bağlılığın algılanan örgütsel toksisite ile iş doyumu arasındaki ilişkide kısmi aracı rolü bulunmaktadır. Bu doğrultuda, bireylerin algıladıkları örgütsel toksisiteye bağlı olarak iş doyumu ve duygusal bağlılık düzeylerinin azaldığı söylenebilir. Araştırmanın bulguları, geliştirilen modelin desteklendiğini göstermektedir. Özetle, araştırma görevlilerinin örgütsel toksisite algılarının iş doyum düzeyleri üzerinde doğrudan, negatif yönde ve anlamlı bir etkiye sahiptir. Aynı zamanda araştırma görevlilerinin örgütsel toksisite algıları kurumlarına ilişkin duygusal bağlllık düzeyleri üzerinden araştırma görevlilerinin iş doyum düzeylerini dolaylı bir şekilde düşük bir oranda etkilemektedir. Algılanan örgütsel toksisitenin iş doyumu üzerindeki doğrudan etki 
oranı $(\Omega=-.42, \mathrm{p}<0.01)$ dolaylı etki $(\Omega=-.19, \mathrm{p}<0.01)$ oranından daha yüksek düzeydedir.

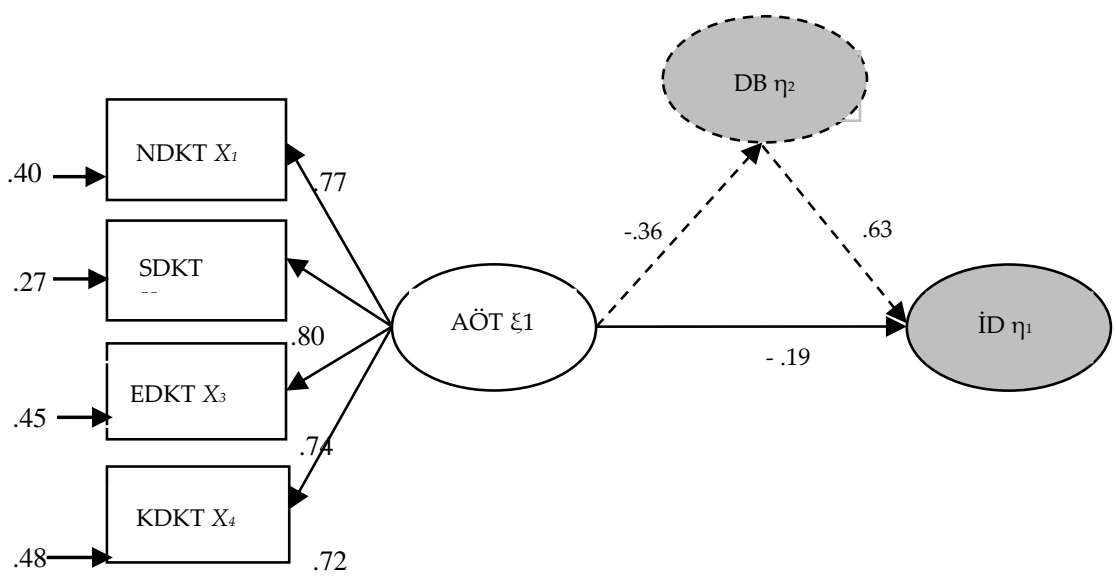

Şekil 2. Algılanan örgütsel toksisite ve örgütsel sonuçlarına ilişkin yapısal eşitlik modeli

\section{Sonuç ve Tartışma}

Bu araştırmada, i)araştırma görevlilerinin örgütsel toksisite algıları, iş doyumları ve kurumlarına ilişkin duygusal bağlılıkları arasında ilişkiler Pearson korelasyon katsayısı ve ii) araştırma görevlilerinin örgütsel toksisite algıları ile iş doyumları arasındaki ilişkide duygusal bağlılığın aracı etkisi de oluşturulan yapısal eşitlik modelleri ile incelenmiştir.

Araştırma görevlilerinin örgütsel toksisite algıları ve boyutları ile iş doyumları arasında negatif ve anlamlı ilişkiler vardır. Bu bulgu, örgütsel toksisiteyi algılayan araştırma görevlilerinin iş doyumu düzeylerinin azalacağ1 şeklinde yorumlanabilir. İlhan, Özkan, Kurtcebe ve Aksakal (2009) çalışmalarında, araştırma görevlilerinin yüksek oranda duygusal/sözel şiddete maruz kaldıklarını belirtmişlerdir. Yılmaz ve Şahin (2016) de çalışmalarında, araştırma görevlilerinin evrak ve angarya işler ile uğraştıkları, öğretim üyelerinin özel işlerini yaptıkları, akademik çalışmalarını 
baskı ve müdahaleye maruz kalarak gerçekleştirdikleri için kendilerini rahatsız ve kullanıldıklarını düşündükleri bulgularını elde etmişlerdir. Fakülte, bölüm veya enstitünün verdiği idari işleri yapan (Korkut, Muştan ve Yalçınkaya, 1999), ders ve sınav programı hazırlama, sosyal etkinlik ve törenlerde görev alma gibi idari işleri de kapsayan "alt düzey kimliklenen eylemleri" (Turhan ve Erol, 2017) gerçekleştiren araştırma görevlilerinin, iş doyumlarının yüksek olması da beklenen bir durum değildir (Dağdeviren, Musaoğlu, Kurt Ömürlü ve Öztora, 2011; Gülnar, 2007; Öztürk ve Şahbudak, 2017; Şahal, 2005; Urlu, 2010). Dolayısıyla kurumlarını zehirli algılayan araştırma görevlilerinin iş doyum düzeylerinde de düşüş gerçekleşebilir.

Araştırma da ayrıca, araştırma görevlilerinin algılanan örgütsel toksisite ve boyutları ile kurumlarına ilişkin duygusal bağlılıkları arasında negatif ve anlamlı ilişkiler bulunmaktadır. Bu bulgu, örgütsel toksisiteyi algılayan araştırma görevlilerinin kurumlarına ilişkin duygusal bağlılık düzeylerinin azalacağı şeklinde yorumlanabilir. Araştırma görevlilerinin kurumlarında acı veren toksinlere maruz kalmaları kurumlarına ilişkin duygusal bağlılık düzeylerinde düşüşe neden olabilir. Araştırmanın bu bulgusu, kurumlarında kendilerini "köle", "mahkûm" ve "itaatkâr insanlar" (Akagündüz, 2012; K1sa, 2013) olarak algılayan araştırma görevlerinin kurumlarına ilişkin duygusal bağlılık düzeylerinde düşüşe neden olunduğunu belirten araştırmalarla (Boylu, Pelit ve Güçer, 2007; Tekin ve Birincioğlu, 2017) paralellik göstermektedir.

Algılanan örgütsel toksisitenin iş doyumu üzerindeki doğrudan etkisini belirlemek üzere oluşturulan birinci modelde, bağımsız değişken olarak algılanan örgütsel toksisite ve bağımlı değişken olarak iş doyumu yer almıştır. Path analizi sonuçları, algılanan örgütsel toksisitenin iş doyumu üzerinde negatif yönde yordayıcı olduğu saptamıştır. Buna göre, kurumlarının etik dışı, narsisit, saldırgan ve katı davranışlı toksinler tarafından zehirlendiğini algılayan araştırma görevlilerinin iş doyum düzeyleri azalabilir. Toksinlerin oluşturduğu toksisite, bir enfeksiyon ve salgin bir hastalık gibi kurumda yayıldığı zaman örgütlerde patolojik durumlara yol açarak (Goldman, 2009; Kets de Vries, 2007) işgörenlerin zehirlenmesine neden olabilmektedir. Böylece örgütsel toksisitenin olumsuz etkisiyle birey, işine odaklanmakta zorlanacak, çalışma azmi azalacak, kariyeri tahrip olacak ve çalışma ortamında bulunmak istemeyecektir (Frost, 2003; Lubit, 
2003; Porter-O'Grady ve Malloch, 2010). Alanyazın incelendiğinde, lider kaynaklı toksik davranışları algılayan bireylerin iş doyumu puanlarının düşük olduğu belirlenmiştir (Mackie, 2008; Mehta ve Maheshwari, 2013; Schmidt, 2008; Webster, Brough ve Daly, 2016). İşgörenler, bireysel hedeflerini elde etmek amacıyla, gerektiğinde birbirlerine yönelik kaba ve nezaketsiz davranışlar sergileyebilmekte (Kanten, 2014), aşağılayıcı mesajlar verebilmekte, kıskançlık davranışları gösterebilmekte ve bu davranışları kendi çıkarları doğrultusunda sürdürebilmektedirler. Bu tarz toksinler ile akademik ortamların zehirlenmesiyle birlikte, araştırma görevlilerinin de iş doyum düzeylerinde düşüş göstermeleri söz konusu olabilir.

Algılanan örgütsel toksisite ile iş doyumu arasında duygusal bağlılığın aracılığını belirlemek üzere oluşturulan ikinci modelde, bağımsız değişken olarak algılanan örgütsel toksisite, bağımlı değişken olarak iş doyumu ve aracı değişken olarak duygusal bağlılık yer almıştır. Path analizi sonuçları, duygusal bağlılı̆̆ın algılanan örgütsel toksisite ile iş doyumu arasında kısmi aracılık rolünün olduğunu saptamıştır. Duygusal bağlılığın algılanan örgütsel toksisite ile iş doyumu arasındaki aracılık rolü, örgütsel toksisite ile iş doyumu arasındaki doğrudan ilişkinin gücünün azalttığında görülmektedir (Şekil 2, Tablo 3). Buna göre; akademik ortamda toksisite algısının azalmasıyla birlikte iş doyumu ve duygusal bağlılık düzeyleri artacaktır. Akademik ortamın geneline yayılan toksik davranışların oluşturduğu toksik durumlar zamanla örgüt kültürünün bir parçası haline gelebilir. Dolayısıyla, örgütsel toksisitenin tüm kurum üyeleri tarafından önemsenmesi ve sorunun kurumun bütününe yayılmadan çözülmesi için özellikle bireylerin iş doyumu ve duygusal bağlllık düzeyleri artıracak düzenlemelerde bulunmak yararlı olabilir. Bu bulgu, iş yaşamında toksik davranışlar ile iş doyumu ve duygusal bağlllık gibi örgütsel çıktıları arasındaki ilişkileri ele alan kurumsal yaklaşımları destekler niteliktedir (Frost, 2003; Kusy ve Holloway, 2009; Peterson ve Deal, 2009; Steele, 2011). Bireyler çalıştıkları kurumda adil muamele gördükleri zaman, çok daha az acı yaşamakta; çok daha fazla canlılık, üretkenlik, sadakat ve bağlılık ortaya çıkmaktadır (Frost, 2003). Dolayısıyla kurumlarda acı veren zehirli ortamlardan bireyleri koruyabilmek adına bireylere saygılı ve onurlu davranışlar sergileyerek, onları toplumun ya da ailenin bir parçası olarak gören sistemlerin içine dâhil ederek (Frost, 2004), adil çalışma 
ortamları oluşturarak iş doyumları ve duygusal bağlılık düzeyleri artırılabilir.

Araştırmanın sınırlılıkları göz ardı edilmeden, araştırma görevlilerinin örgütsel toksisite algıları ile iş doyumları ve duygusal bağlılıkları arasındaki ilişkilerin negatif yönde olduğu sonucuna ulaşılmıştır. Geliştirilen birinci modelde, akademik ortamlarda algılanan örgütsel toksisitenin iş doyumu üzerinde olumsuz yönde ve doğrudan etkisinin olduğu sonucuna ulaşılmıştır. Bu sonuç, akademik ortamlarda örgütsel toksisite algılarını düşürerek iş doyumlarını artırılabileceği biçiminde yorumlanabilir. Geliştirilen ikinci modelde, akademik ortamlarda algılanan örgütsel toksisitenin iş doyumu üzerinde olumsuz yönde ve dolaylı etkisinin olduğu; duygusal bağlılığın da aracı bir rolü olduğu belirlenmiştir. Bu durum, duygusal bağlılık ile iş doyumu düzeylerinde artışın sağlanmasında örgütsel toksisitenin rolünün olduğunu göstermektedir.

Araştırmadan elde edilen tüm bu sonuçlar ışığında, örgütsel toksisite, iş doyumu ve duygusal bağl1lık değişkenlerinin birbirleriyle olan ilişkileri ele alan bu çalışmanın ilgili alanyazına katkı sağlayacağı düşünülmektedir. Farklı hizmet alanlarına sahip kurumlarda, benzer araştırmaların yinelenmesi de bulguların genellenebilirliği açısından önemli görülmektedir. Alanyazın incelendiğinde, iş yaşamında toksisite çalışmalarının sağlık (Roter, 2011), eğitim (Bolton, 2005; Buehler, 2009; Çelebi ve Yıldız, 2015; Kırbaç, 2013), savunma (Aubrey, 2013; Black, 2015; Mueller, 2012; Schmidt, 2008; Steele, 2011) ve turizm (Unur ve Pekerşen, 2017) alanlarını kapsayan kurumlarda ele alındığı görülmektedir. Dolayısıyla bu araştırmanın özellikle yükseköğretim düzeyinde bir eğitim alanındaki kurumunda yürütülmüş olması, hem alanyazına önemli bir katkı sağlayacak hem de yükseköğretim kurumlarındaki sosyal dinamiklerin anlaşılmasına olanak sunacaktır. Son olarak, algılanan örgütsel toksisitenin çeşitli örgütsel çıtılar üzerindeki etkileri ve çeşitli örgütsel çıtılar ile ilişkilerinin incelenmesi dikkat çekilebilir. Ayrıca, örgütsel toksisitenin algılanmasına neden olan örgütsel öncüllerin ilişkileri ve etkilerinin de ele alınması mümkündür. Gelecekteki araştırmalarda örgütsel toksisitenin farklı örgütsel çıtılar ile ilişkileri ve üzerindeki etkilerinin test edilmesi önerilebilir. 
EXTENDED ABSTRACT

\section{The Effect of Perceived Organizational Toxicity on Job Satisfaction: The Mediating Role of Affective Commitment}

*

Gamze Kasalak

Akdeniz University

Organizational toxicity is defined as "a situation that causes employees to suffer and have problems, reduces interest in their jobs by negatively affecting their morale and motivation" and "pains that destroy employees' self-confidence and dignity at workplace" (Frost, 2003, p.13-14). Toxins leak into institutions and spread at various levels and without being noticed most of the time (Frost, 2003). In the literature, it has been stated that organizational toxicity affects important organizational outcomes such as job satisfaction (Mackie, 2008; Mehta \&Maheshwari, 2013; Schmidt, 2008; Tepper, 2000; Webster, Brough \& Daly, 2016) and affective commitment (Holloway \& Kusy, 2010; Mehta \& Maheshwari, 2013; Middleton, 2018). The purpose of the study is to examine the relationships among perceived organizational toxicity, affective commitment and job satisfaction. The research questions are as follows; 1) Is there a significant correlation among the research variables? 2) Do the affective commitment plays a mediating role between perceived organizational toxicity and job satisfaction?

The study which concentrates on the relationships between percived organizational toxicity, job satisfaction and affective commitment is a correlational survey model. The sample of the study consists of 253 research assistants, working at four state universities located in the Mediterranean Region in Turkey, who were selected by stratified sampling method. In terms of their academic fields, the distributions of the samples are as follows: at the institute of social sciences (49.6\%), the institute of natural and applied sciences (30.1\%), the institute of medical sciences (20.3\%), and the institute of fine arts. Ages range from 23 years to 36 years, with the mean of 28.7 years. Their lengths of services change in their universities between 1-14 years with the mean of 3.6. The data were collected through i) perceived organizational toxicity scale which was developed by Kasalak (2015); 
ii) job satisfaction scale which was developed by Brayfield \& Rothe (1951) and was translated and adapted into Turkish by Bilgin (1995); iii) affective commitment scale which was developed by Allen \& Meyer (1990) and was translated and adapted into Turkish by Wasti (2000). The relations between the perceived organizational toxicity, the job satisfaction and affective commitment were examined through Pearson correlation coefficient. That whether perceived organizational toxicity (independent variable) were a significant predictor of job satisfaction (the dependent variable) and affective commitment (mediating role) were examined using structural equation modeling.

Job satisfaction is the strongest variable $[\mathrm{M}=3.64, \mathrm{SS}=0.75]$ while perceived organizational support weakest variable $[\mathrm{M}=2.58, \mathrm{SS}=0.73]$. When the Pearson product-moment correlation coefficients are examined, negative and significant relationships between all dimensions of perceived organizational toxicity and affective commitment are found. While affective commitment was moderate negatively correlated with toxicity based on narcissist behaviours $(\mathrm{r}=-0.321, \mathrm{p}<0.01)$ and general perceived organizational toxicity $(\mathrm{r}=-0.335, \mathrm{p}<0.01)$; it was low-level negatively correlated with toxicity based on aggressive behaviours $(\mathrm{r}=-0.299, \mathrm{p}<0.01)$, toxicity based on unethical behaviours $(r=-0.245, p<0.01)$ ve toxicity based on rigid behaviours $(r=-0.255, p<0.01)$. And also, there are negative and significant relationships between all dimensions of perceived organizational toxicity and job satisfaction. Whereas job satisfaction was moderate negatively correlated with general perceived organizational toxicity $(\mathrm{r}=-0.351$, $\mathrm{p}<0.01)$ and toxicity based on narcissist behaviours $(\mathrm{r}=-0.369, \mathrm{p}<0.01)$; it was low-level negatively correlated with toxicity based on aggressive behaviours $(\mathrm{r}=-0.277, \mathrm{p}<0.01)$, toxicity based on unethical behaviours $(\mathrm{r}=$ $0.281, p<0.01)$ and toxicity based on rigid behaviours $(r=-0.250, p<0.01)$. Positively significant correlations at moderate levels were obtained between the job satisfaction and the affective commitment $(r=0.589$, $\mathrm{p}<0.01$ ). In the study, the mediating effect of affective commitment between percived organizational toxicity (independent variable) and job satisfaction (dependent variable) were examined. Percived organizational toxicity is a significant predictor of job satisfaction $(\Omega=-.19, \mathrm{p}<0.01)$. Similarly, percived organizational toxicity predicts affective commitment significantly $(B=-.36, p<0.01)$. The mediating effect of affective commitment 
between perceived organizational toxicity and job satisfaction was examined by means of path analysis. Goodness of fit statistics also supports these findings $\chi 2=82.25 ; \mathrm{sd}=26, \mathrm{p}=0.00<0.01 ; \chi 2 / \mathrm{sd}=3.16$; $\mathrm{RMSEA}=0.093$; GFI 0.93 ; AGFI $=0.88 ; \mathrm{NFI}=0.93 ; \mathrm{CFI}=0.95$, IFI $=0.95$ ve $\mathrm{SRMR}=0.066$ ] for Model 1 and $[\chi 2=239.28 ; \mathrm{sd}=87, \mathrm{p}=0.00<0.01 ; \chi 2 / \mathrm{sd}=2.75 ; \mathrm{RMSEA}=0.083$; $\mathrm{GFI}=0.89$; $\mathrm{AGFI}=0.84 ; \mathrm{NFI}=0.94 ; \mathrm{CFI}=0.96, \mathrm{IFI}=0.96$ ve $\mathrm{SRMR}=0.060]$ for Model 2.

Without considering the limitations of the research, it has been concluded that the relationship between the organizational toxicity perceptions of the research assistants and their job satisfaction and affective commitment is negative. In the first model, it was concluded that the perceived organizational toxicity has a negative and direct effect on job satisfaction. This result can be interpreted as decreasing organizational toxicity perceptions in work environments can increase job satisfaction. The negative effect of organizational toxicity on job satisfaction was found in the second model, which has a mediating role for affective commitment. This shows that organizational toxicity plays a role in increasing affective commitment and job satisfaction levels. This study, which deals with the relationship between organizational toxicity, job satisfaction and emotional commitment variables, is thought to contribute to the related literature. Finally, for the future research, it is recommended that organizational toxicity should be tested in relation to different organizational outcomes and premises.

\section{Kaynakça / References}

Akagündüz, Ü. Ö. (2012). Akademik köleler. Aksiyon, 891, 34-39. http://www.aksiyon.com.tr/kapak/akademik-koleler_531397 adresinden erişildi.

Appelbaum, S. H.ve Roy-Girard, D. (2007). Toxins in the workplace: affect on organizations and employees. Corporate Governance: The International Journal of Business in Society, 7(1), 17-28.

Aubrey, D. W. (2013). Operationalizing the construct of toxic leadership in the United States Army. Yayınlanmamış doktora tezi, University of Phoenix, Arizona, USA.

Bilgin, N. (1995). Sosyal psikolojide yöntem ve pratik çalışmalar, İstanbul: Sistem Yayincilik, 
Black, J. A. (2015). The lived experiences of the army officer's wife to an army commander's toxic leadership: A phenomenological study. Yayınlanmamış doktora tezi, Capella University, Minneapolis, USA.

Bolton, S.C. (2005). Emotion management in the workplace (Management, work and organisations). New York: Palgrave Macmillan.

Boylu, Y. ve Güçer, E.(2007). Akademisyenlerin örgütsel bağlılık düzeyleri üzerine bir araştırma, Finans Politik E Ekonomik Yorumlar 44 (511), 5574.

Buehler, J. L. (2009). Words matter: The role of discourse in creating, sustaining and changing school culture. Yayınlanmamış doktora tezi, The University of Michigan, Michigan, USA.

Büyüköztürk, Ş. (2005). Anket geliştirme. Türk Eğitim Bilimleri Dergisi. 3(2), 133-148.

Carlock, D.H. (2013). Beyond bullying: A holistic exploration of the organizational toxicity phenomenon. Yayınlanmamış doktora tezi, Pepperdine University, California, USA.

Çelebi, N., Yıldız, V. ve Güner, H. (07-09 Kasım 2013). İlköğretim birinci ve ikinci kademe öğretmenlerinin toksik liderlik algıları. VIII. Ulusal Ĕğitim Yönetimi Kongresi'nde sunulan bildiri. İstanbul. http://eyk8.marmara.edu.tr/bildiri_ozetleri_kitabi.pdf adresinden erişildi.

Dağdeviren, N., Musaoğlu, Z., Kurt Ömürlü, İ. ve Öztora, S. (2011). Akademisyenlerde iş doyumunu etkileyen faktörler. Balkan Medical Journal, 28, 69-74

Dotan, H. (2009). Workplace Friendships: Origins and Consequences for Managerial Effectiveness. The Annual Meeting of the Academy of Management. Chicago, Illinois: Academy of Management.

Friedman, T. L. (2005). The world is flat. New York: Picador.

Frost, P. J. (2003). Toxic emotions at work: How compassionate managers handle pain and conflict. Boston: Harvard Business School Press.

Frost, P. J. (2004). Handling toxic emotions: New challenges for leaders and their organization, Organizational Dynamics, 33(2), 111-127.

Gangel, K.O. (2007). Surviving toxic leaders: How to work for flawed people in churches, schools, and Christian organization. USA: Wipf \& Stock Publishers.

Goldman, A. (2009). Transforming toxic leaders. California: Stanford University Press. 
Gülnar, B. (2007). Araştırma görevlilerinin iş tatminini sağlama aracı olarak örgütsel iletişim ve iletişim doyumu: Kamu ve özel üniversite karşılaştırması (Yayımlanmamış doktora tezi). Selçuk Üniversitesi, Sosyal Bilimler Enstitüsü, Konya, Türkiye.

Hançerlioğlu, O. (2000). Felsefe ansiklopedisi: Kavramlar ve akımlar cilt 1 (A-D). İstanbul: Remzi Kitabevi.

Holloway, E. L. ve Kusy, M. E. (2010). Disruptive and toxic behaviors in healthcare: zero tolerance, the bottom line, and what to do about it. The Journal of Medical Practice Management: MPM, 25(6), 335-340.

Holmbeck, G. N. (1997). Toward terminological, conceptual, and statistical clarity in the study of mediators and moderators: Examples from the child-clinical and pediatric psychology literatures. Journal of Counting and Clinical Psychology, 65(4), 599-610

İlhan, M. N., Özkan, S., Kurtcebe, Z. Ö. ve Aksakal, F. N. (2009). Gazi Üniversitesi Tıp Fakültesi Hastanesinde çalışan araştırma görevlileri ve intörn doktorlarda şiddete maruziyet ve şiddetle ilişkili etmenler. Toplum Hekimliği Bülteni, 28 (3), 15-23.

Turhan, M. ve Erol, Y.C. (2017). Araştırma görevlilerinin eylem kimlikleme biçimleri, Turkish Journal of Educational Studies, 4 (3), 105-121.

Jonason, P. K., Slomski, S. ve Partyka, J. (2012). The Dark Triad at work: How toxic employees get their way. Personality and Individual Differences, 52(3), 449-453.

Kanten, P. (2014). İşyeri nezaketsizliğinin sosyal kaytarma davranışı ve işten ayrılma niyeti üzerindeki etkisinde duygusal tükenmenin aracılık rolü. Aksaray Üniversitesi İktisadi ve İdari Bilimler Fakültesi Dergisi, 6(1), 11-26.

Kasalak, G. (2015). Yükseköğretimde örgütsel toksisite: Kaynakları, etkileri ve başa çıkma stratejileri. Yayınlanmamış doktora tezi, Akdeniz Üniversitesi, Antalya.

Kets De Vries, M.F.R. (2007). Liderliğin gizemi: İşletmelerde liderlik davranışı (Zülfü Dicleli, çev.). İstanbul: Mess Yayınları.

Kırbaç, M. (2013). Eğitim örgütlerinde toksik liderlik. Yayımlanmamış yüksek lisans tezi, İnönü Üniversitesi, Eğitim Bilimleri Enstitüsü, Malatya.

Kısa, N. (2013). Araştırma görevlilerinin metaforik algıları: Kim onlar? Kim olmalılar?.Mehmet Akif Ersoy Üniversitesi Eğitim Fakültesi Dergisi, 28, 47-66 
Kline, R. B. (2005). Principle and practice of structural equation modeling. New York, NY: Guilford.

Korkut, H., Muştan, T., ve Yalçınkaya, M. (1999). Araştırma görevlilerinin sorunları. Kuram ve Uygulamada Eğitim Yönetimi Dergisi, 17, 19-36.

Kusy, M. ve Holloway, E. (2009).Toxic workplace! Managing toxic personalities and their systems of power. San Francisco, CA: Jossey-Bass.

Leet, E. (2011). The impact toxic or Severe dysfunctional leadership has on the effectiveness of an organization. Yayınlanmamış doktora tezi, Murdoch University, Australia.

Lipman-Blumen, J. (2005). The allure of toxic leaders: Why followers rarely escape their clutches. Ivey Business Journal, 69(3), 1-40.

Lubit, R. H. (2003). Coping with toxic managers, subordinates... and other difficult people: Using emotional intelligence to survive and prosper. NJ: Financial Times Prentice Hall.

Mackie D (2008). Leadership derailment and psychological harm, InPsych 30(2): 12-13.

Maitlis, S. (2008). Organizational toxicity. In S. Clegg ve J. Bailey (Eds). International encyclopedia of organization studies. Thousand Oaks: Sage Publications.

Mathieu, C., Neumann, C. S., Hare, R. D., ve Babiak, P. (2014). A dark side of leadership: Corporate psychopathy and its influence on employee well-being and job satisfaction. Personality and Individual Differences, 59, 83-88. http://dx.doi.org/10.1016-/j.paid.2013.11.010

Mehta, S. ve Maheshwari, G. C. (2013). Consequence of toxic leadership on employee job satisfaction and organizational commitment. Journal of Contemporary Management Research, 8(2), 1-23.

Meyer, J. P.; ve Allen, N. J. (1991). A three-component conceptualization of organizational commitment. Human Relations, 1, 61-89

Mueller, R. A. (2012). Leadership in the US Army: A qualitative exploratory case study of the effects toxic leadership has on the morale and welfare of soldiers. Yayınlanmamıs doktora tezi, Capella University, Minnesota, USA.

Musacco, S. D. (2009). Beyond going postal: Shifting from workplace tragedies and toxic work environments to a safe and healthy organization. Charleston, SC: BookSurge Publishing. 
O'Boyle, E.H., Forsyth, D.R., Banks, G.C., ve McDaniel, M.A.(2012). A metaanalysis of the Dark Triad and work behavior: a social exchange perspective. The journal of applied Psychology, 97(3):557-79. doi: 10.1037/a0025679.

O'Leary-Kelly, A. M., Griffin, R. W., ve Glew, D. J. (1996). Organization-motivated aggression: A research framework. Academy of Management Review, 21(1), 225-253.

Online Etymology Dictionary (2014). Toxicity. http://www.etymonline.com/index.php?allowed_in_frame $=0 \&$ search $=$ toxicity\&searchmode $=$ none adresinden erişildi.

Öztürk, M. ve Şahbudak, E. (2017). İşyerinde psikolojik taciz (mobbıng) ve iş doyumu: Cumhuriyet üniversitesindeki araştırma görevlileri üzerine bir çalışma, Sosyoloji Araştırmaları Dergisi, 20(2), 200-228.

Pelletier, K. L. (2009). The effects of favored status and identification with victim on perceptions of and reactions to leader toxicity. Yayınlanmamış doktora tezi, Claremont Graduate University, California, USA.

Pelletier, K. L. (2012). Perceptions of and reactions to leader toxicity: Do leader-follower relationships and identification with victim matter? The Leadership Quarterly, 23(3), 412-424.

Peterson, K.D. ve Deal, T.E. (2009). The shaping school culture fieldbook. San Francisco, CA: Jossey-Bass

Porter-O'Grady, T. ve Malloch, K. (2010). Quantum leadership: A resource for health care innovation. Sudbury, MA: Jones \& Bartlett.

Riley R., Hatfield, J., Nicely, K., Keller-Glaze, H. ve Steele J.P. (2011). 2010 Center for army leadership annual survey of army leadership (CASAL): Main findings.Volume 2, Main Findings (No. TR-2011-1-VOL-2). ICF INTERNATIONAL INC FAIRFAX VA.

Roter, A. B. (2011). The lived experiences of registered nurses exposed to toxic leadership behaviors. Yayınlanmamış doktora tezi, Capella University, Minneapolis, USA.

Schermelleh-Engel, K., Moosbrugger, H. ve Müller, H. (2003). Evaluating the fit of structural equation models: Tests of significance and descriptive goodness-of-fit measures. Methods of Psychological Research Online, $8(2), 23-74$.

Schmidt, A.A. (2008). Development and validation of the toxic leadership scale. Yayınlanmamış yüksek lisans tezi,. University of Maryland, College Park, USA. 
Steele, J.P. (2011). Antecedents and consequences of toxic Leadership in the U. S. Army: A two year review and recommended solutions (Technical Report). Fort Leavenworth, KS: Center for Army Leadership Annual Survey of Army Leadership (CASAL).

Sümer, N. (2000). Yapısal eşitlik modelleri: Temel kavramlar ve örnek uygulamalar. Türk Psikoloji Yazıları, 3(6), 4-74.

Şahal, E. (2005). Akademik örgütlerde örgüt kültürü ve iş tatmini arasındaki ilişki: Akdeniz Üniversitesi'nde doktora yapan araştırma görevlilerinin örgüt kültürüne ve iş tatminine yönelik algı ve kanaatleri (Yayımlanmamış yüksek lisans tezi). Akdeniz Üniversitesi, Sosyal Bilimler Enstitüsü, Antalya, Türkiye.

Tekin, E. ve Birincioğlu, N. (2017). Araştırma görevlilerinin örgütsel bağlılık düzeylerinin kadro türü ve demografik özellikler açısından incelenmesi, Uluslararası İktisadi ve İdari Incelemeler Dergisi. (19), 171-196

Türk Dil Kurumu (TDK) (2015). Acı. http://www.tdk.gov.tr/index.php?-option=com_bts\&arama=kelime\&guid=TDK.GTS.5624929c3bdb23.1483721 adresinden erişildi.

Twenge, J. M. ve Campbell, W., K. (2010). Asrın vebası: Narsisizm illeti (Özlem Korkmaz, çev.). İstanbul: Kaknüs Yayınları.

Urlu, F. (2010). İş tatmini unsurları: Sakarya Üniversitesi araştırma görevlileri örneği (Yayımlanmamış yüksek lisans tezi). Sakarya Üniversitesi, Sosyal Bilimler Enstitüsü, Sakarya, Türkiye.

Unur, K. ve Pekerşen, Y. (2017). İş Stresi İle Toksik Davranışlar Arasındaki İlişki: Aşçılar Üzerinde Bir Araştırma. Seyahat ve Otel İşletmeciliği Dergisi, 14 (1), 2017, 108-129

Walton, M. (2007). Leadership toxicity - An inevitable affliction of organisations? Organisatıons \& People, 14(1), 19-27.

Wasti, S. A. (2000). Meyer ve Allen'in üç boyutlu örgütsel bağlılık ölçeğinin geçerlilik ve güvenilirlik analizi. 8. Ulusal yönetim ve organizasyon kongresi, 25-27.

Webster, V., Brough, P., ve Daly, K. (2016). Fight, flight or freeze: common responses for follower coping with toxic leadership. Stress and Health, 32(4), 346-354.

Whicker, M.L. (1996). Toxic leaders: When organizations go bad. Westport, Conn: Quorum Books.

Wiener, Y. (1982). Commitment and Organizations: A Normative View, Academy of Management Review, 7 (3), 418-428. 
Yılmaz, K. ve Şahin, T. (2016). Eğitim fakültelerindeki araştırma görevlilerinin mesleki deneyimlerinin incelenmesi: araştırma görevlisi olmanın anlamına ilişkin fenomenolojik bir çalışma. Marmara Üniversitesi Atatürk Eğitim Fakültesi Eğitim Bilimleri Dergisi, 44, 143-168, DOI: 10.15285/maruaebd.286491.

\section{Kaynakça Bilgisi / Citation Information}

Kasalak, G. (2019). Algılanan örgütsel toksisitenin iş doyumu üzerine etkisi: Duygusal bağlılığın aracılık rolü. OPUS-Uluslararası Toplum Araştırmaları Dergisi, 13(19), 1283-1309. DOI: 10.26466/opus.537424 